\title{
Planning for social and community-engaged closure: A comparison of mine closure plans from Canada's territorial and provincial North
}

\author{
Miranda Monosky ${ }^{\mathrm{a}}$, Arn Keeling ${ }^{\mathrm{a}}$ \\ a Department of Geography, Memorial University of Newfoundland, St. John's, NL A1C 5S7, \\ Canada \\ Corresponding author \\ E-mail address: mnmonosky@mun.ca (M. Monosky) \\ Highlights:
}

- Mine closure plans do not clearly explain methods or outcomes of community engagement

- Indigenous Knowledge is inconsistently used in closure planning

- The socio-economic impacts of mine closure are not well acknowledged

- Few concrete strategies are proposed to mitigate the socio-economic aspects of closure

\begin{abstract}
The inevitable closure and remediation phase of a mine's lifecycle routinely causes negative socio-economic and environmental impacts for nearby communities. While closure planning is meant to ensure post-closure human and environmental safety, it tends to favour short-term technical fixes over longer-term socio-economic, cultural, and ecological considerations. For mines operating on Indigenous territories, where communities have complex and nuanced connections to land and varying levels of jurisdiction, these issues are further exacerbated by the exclusion of Indigenous voices from planning and decision-making. This research employed a qualitative document analysis of ten mine closure plans for mines in Northern Canada that are still operational to understand how the industry is actively planning for the closure and remediation of their sites. In particular, this work asks whether or not mine companies are incorporating Indigenous Knowledge into their mine closure plans, and how they are addressing the complex socio-economic aspects of closure. This analysis showed that mine closure plans across Northern Canada inconsistently apply Indigenous Knowledge and expertise, and the methods used for community consultation in mine closure planning are left vague. While differences in policy between Northern territories and regions account for some of these inconsistencies, a company's willingness to work beyond baseline requirements imposed by governments is also an important factor. Additionally, these closure plans further demonstrate that the industry prioritizes technical aspects of mine closure over the social, cultural, economic, and ecological. For mine closure to be successful in a Northern context it must incorporate community expertise, emerge from the values and priorities of the Indigenous peoples whose lands mines are operating on, and account for a wider scope of social, economic, and cultural impacts.
\end{abstract}

Keywords: extractive industries, mine closure, remediation, Indigenous communities, Northern Canada 


\section{Introduction}

Mine closure and remediation (also known as rehabilitation or reclamation) include all the planning and actions required to shut down a mine after it is no longer viable for operations. This includes the methods for physically cleaning up the site - removing infrastructure, filling pits, containing and stabilizing waste - and post-closure monitoring to ensure no hazards are remaining that threaten the land, animals, and humans in proximity to the site. Historically, the volatility of mineral markets and the industry's boom-bust cycles meant that often closure happened abruptly and sites were abandoned entirely by bankrupt companies (Laurence, 2006; Sandlos and Keeling, 2016). In other cases, companies were only minimally penalized for not complying with often lax reclamation requirements. The result has been a plethora of abandoned and poorly remediated mine sites around the world that eventually became the responsibility of national or regional governments (Worrall et al., 2009). Since the 1990s, best-practice guidelines have increasingly recognized the importance of closure and remediation in the ecological and economic sustainability of individual mines and the industry as a whole (Cowan et al., 2010; International Council on Mining \& Metals, 2019a; Laurence, 2006; Sánchez et al., 2014; Kabir et al., 2015). Regulations governing mine closure have also become more robust. Nevertheless, closure planning continues to receive less attention compared to the development and operations phases, and remains largely focused on the physical aspects of remediation while neglecting social, economic, and cultural impacts (Bainton and Holcombe, 2018; Langhorst and Bolton, 2017; Vivoda et al., 2019).

Mine closure plans are the instruction manuals for closure. They explain precisely the closure and remediation activities for a given mine site, and outline post-closure objectives (International Council on Mining \& Metals, 2019b). In Canada, these plans are typically drafted at the beginning of a mine's life by consultants specializing in mine remediation and hired by the mine company. They are submitted to the relevant provincial/territorial government for approval, and then resubmitted for reapproval every five years until closure. A mine's lifespan can range anywhere from two to thirty or more years, so some closure plans are revised several times. Thus, closure plans represent a convergence of government policy and company practices: while regulatory regimes control many aspects of mine closure, gaps in these regimes and the specific features of individual mine sites create space for interpretation by mine operators (Dance et al., 2020; Kabir et al., 2015). Thus, an examination of closure plans can point to both gaps in public policy and the shortcomings of industry practices.

Depending on the region in which the mine is operating, a closure plan may undergo different levels of government or public review. Despite their importance, however, closure plans are rarely the subject of critical academic review, with focus instead being placed on documenting the failures of past closures and mine abandonments (e.g. Archer and Bradbury, 1992; Bainton and Holcombe, 2018; Boutet, 2014; Bowes-Lyon et al., 2009; Green, 2015; Lim, 2013; Rodon and Lévesque, 2015). In Kabir et al.’s (2015) examination of ten Canadian and Australian closure plans, the authors found that these documents inadequately address social impact assessment, community consultation, and post-closure monitoring. This research builds on these results, focusing more specifically on company strategies for addressing socio-economic impacts, engaging with communities, and incorporating local knowledge into closure plans in a specific geographical context, Northern Canada. 
This paper systematically reviews and compares ten mine closure plans from mines currently operating in Northern Canada to determine how companies understand and address many of the critical social, economic, and cultural aspects of closure identified in the literature. This analysis involved collecting publicly available (or requested) mine closure plans and extracting text that addresses the following issues: (1) how mine companies engage with communities for closure planning; (2) how company plans utilize knowledge gained from communities, and (3) how these plans address the socio-economic aspects of mine closure. By comparing different approaches to mine closure planning, we were able to determine how public engagement strategies diverge and overlap between companies and across five different Northern territories/regions.

Communities have a wealth of knowledge, experience, and insight that are applicable to every facet of mine closure and remediation. In the context of Northern Canada, local and Indigenous Knowledge are increasingly acknowledged as critical contributors to effective environmental management, from wildlife management to climate change (Parlee, 2012; Tester and Irniq, 2008; Todd, 2014). Once narrowly defined in terms of "traditional” environmental knowledge, Indigenous Knowledge is now widely understood to encompass a holistic, placebased perspective on social and environmental relations, including Indigenous ecological knowledge, values, practices, and worldviews (Cohen, 2017; Horowitz, 2015; McGregor, 2013). Indigenous Knowledge is also integrated into project assessment, review, and permitting processes in each of these Northern jurisdictions--though the effectiveness of these processes in doing so is debated (Ellis, 2004; White, 2006). For mine closure to be successful in a Northern context it must incorporate community expertise, emerge from the values and priorities of the Indigenous peoples whose lands mines are operating on, and account for a wider scope of social, economic, and cultural impacts.

\section{Community engagement and mine closure}

As minerals are a finite resource, closure is an inevitable stage of any mining operation and a normal part of the "mining cycle.” However, closure and decommissioning typically results not from the absolute exhaustion of an orebody, but rather from economic and technical circumstances that render extraction unprofitable (Laurence, 2006; Spitz and Trudinger, 2008). Historically, closure and remediation entailed mainly the physical removal of infrastructure, filling of pits, and containment of hazardous wastes, typically neglecting to address the more complex and interconnected social, economic, and cultural impacts that closure can have on resource-dependent communities (Bainton and Holcombe, 2018; Beckett and Keeling, 2019; Laurence, 2006; Neil et al., 1992). Especially in remote regions, mine closure can cause direct and indirect negative impacts on local and regional industries as contracts end, travel to the region is reduced, and demand for goods and services decreases (Bowes-Lyon et al., 2009; Edwards and Maritz, 2019). Widespread loss of employment, investment, tax revenue, infrastructure, and services and population decline are also common experiences (Archer and Bradbury, 1992; Bradbury and St-Martin, 1983; Lapalme, 2003), resulting in social disruption and stress (Burns and Church, 2018; Edwards and Maritz, 2019; Kendall, 1992; McDonald et al., 2012; Roberts et al., 2000; Rodon and Lévesque, 2015). Furthermore, the benefits promised to local communities by new mine developments, like economic growth and diversification, often fail to meet expectations or last long after closure (Bowes-Lyon et al., 2009; Rodon and Lévesque, 2015; Sandlos and Keeling, 2012). 
National and international guidelines have increasingly emphasized the need to plan for and mitigate these problems well in advance of closure (International Council on Mining \& Metals, 2019a; The Mining Association of Canada, 2008). These guidelines acknowledge the critical importance of engaging early with affected communities in order to develop closure strategies that are effective and appropriate to particular social, cultural, and economic circumstances. If successful, community engagement can result in co-learning between parties, a centering of community needs, values, and concerns, a sense of community ownership and greater social acceptability of remediation plans, greater innovation in closure concepts, designs, and management plans based on diverse perspectives and expertise (Edwards and Maritz, 2019; Hoadley and Limpitlaw, 2008; Veiga et al., 2001). To realize these possibilities, though, community engagement must be carefully planned, executed early in the mine's development, and continue until relinquishment (International Council on Mining \& Metals, 2019a).

In reality, closure planning and community engagement often fall short of these best practices. Consultation and negotiation processes between companies and communities are fraught with challenges, including a lack of trust, inequalities within communities and between parties, and an overreliance on front-end communication during the early stages of the mine's development (Lapalme, 2003; Pini et al., 2010; Vivoda et al., 2019). To date, the literature on community-engaged mine closure is limited to documenting past failures and consultant reports on best practices with few or no real examples of success (Morrison-Saunders, 2019; Stacey et al., 2010; Strambo et al., 2019). Documentation of effective community engagement strategies for socio-economic closure planning is scarce (although see Costa, 2015; Xavier et al., 2015)

Questions of community engagement and participation in mine closure planning are particularly acute for those developments on or proximate to Indigenous territories. Historically, Indigenous peoples in mining regions have often been excluded from the economic and employment benefits of mining, while suffering from mining-induced displacement (Ali, 2003; Bebbington, 2012; Horowitz et al., 2018; Keeling and Sandlos, 2009). Indigenous land use, sovereignty, and self-determination may be negatively affected by large-scale mining development and its long-term environmental impacts (Ballard and Banks, 2003; Howitt, 2001; Jacka, 2018; Parlee, 2012; Rodon, 2018). Recent international trends towards the recognition of Indigenous rights, including the creation of new consultation requirements or governance and benefits-sharing arrangements, have begun to mitigate these impacts and inequities, in some jurisdictions (Bradshaw et al., 2018; O’Faircheallaigh, 2018). Yet it remains unclear how these novel arrangements apply to the long-term social and environmental challenges that emerge at the end of the mining cycle. Mine closure and remediation can generate controversies with Indigenous communities, yet the particular concerns, knowledge, and experiences of these communities in relation to mine closure remain significantly understudied (Horowitz et al., 2018; O’Faircheallaigh and Lawrence, 2019; Tsosie, 2015).

The impacts of closure and remediation on Indigenous communities is especially relevant to the geographical context of Northern Canada. This region includes three territories (Yukon, Northwest Territories, and Nunavut) and the two Northern provincial regions of Nunavik (Quebec) and Nunatsiavut (Newfoundland and Labrador) that are part of Inuit Nunangat. Four of these five jurisdictions include majority Indigenous (First Nation, Métis, and Inuit) populations, and all share similar histories of environmental injustice and dramatic societal change related to mineral extraction and subsequent mine abandonment (Keeling and Sandlos, 2015; Rodon and 
Lévesque, 2015). Furthermore, these regions all have complex governance structures that include: a mosaic of historic treaties and modern land claims agreements; multiple and overlapping Indigenous, regional, and territorial governments; and changing levels of federal and provincial authority and (more recently) devolution. Recent decades have also seen evolving legal requirements and institutional practices around securing Indigenous consent for large-scale resource developments, including the negotiation of Impact and Benefits Agreements (IBAs) between proponents and affected Indigenous groups (Bradshaw et al., 2018; Caine and Krogman, 2010; Cameron and Levitan, 2014; St-Laurent and Billon, 2015). In addition to provisions for financial benefits, employment, and business opportunities, these IBAs may include measures related to the mitigation of environmental impacts, monitoring, and protection of Indigenous land use, although they are frequently confidential (O’Faircheallaigh, 2018; Papillon and Rodon, 2017).

This shifting legal and governance regime has created a complex and inconsistent regulatory environment for mine closure (Dance et al., 2020). Beginning in the 1990s, most jurisdictions in Canada adopted some form of statutory requirement for closure and remediation plans (typically under Mining or Lands acts), as well as policy guidelines. Although varying between provinces and territories, these regulations typically address various aspects of closure, including decommissioning, site stabilization and maintenance, environmental remediation, tailings waste management, water treatment, financial assurance, and (in some cases) conditions for relinquishment of mine lands (Cowan et al., 2010). Remediation projects on Indigenous lands, particularly in Northern Canada, are also governed through regional land and water boards, land claims agreements, and IBAs. However, a recent review concludes that the regulatory landscape remains fragmented and inconsistent across Northern Canada and fails "to adequately appreciate and respond to the complex socio-environmental problems those living near the mines have confronted for decades” (Dance et al., 2020). As the following analysis of mine closure plans across Northern Canada demonstrates, these regulatory shortcomings are at least partially responsible for the troubling gaps and inconsistencies in these plans, including around community engagement, the inclusion of local knowledge and values, and the social dimensions of closure and remediation.

\section{Methods and materials}

This paper focuses on mine closure plans for mineral mines located in Northern Canada that are currently operating, or, more specifically, are in the phase of their lifecycle that is after development and before closure. These criteria included two mines that are not currently in production but have not yet entered closure. Closure documents were initially identified and retrieved through online public registries using keyword searches or manually searching through digital folders and files found on public registries. Because of the limited availability and accessibility of public registries for Nunavik and Nunatsiavut, closure plans from these regions were requested from the companies themselves or via information requests from public agencies. The documents provided by Canadian Royalties (Nunavik) were in their original French form and translated to English before analysis. A total of ten mine closure plans from Yukon $(\mathrm{n}=1)$, NWT ( $n=3)$, Nunavut $(n=3)$, Nunavik $(n=2)$, and Nunatsiavut $(n=1)$ were collected. Figure 1 shows the location of these mine sites, and Table 1 lists basic information about them. All 10 mine sites are operating with an IBA or similar agreement with at least one affected Indigenous community. 


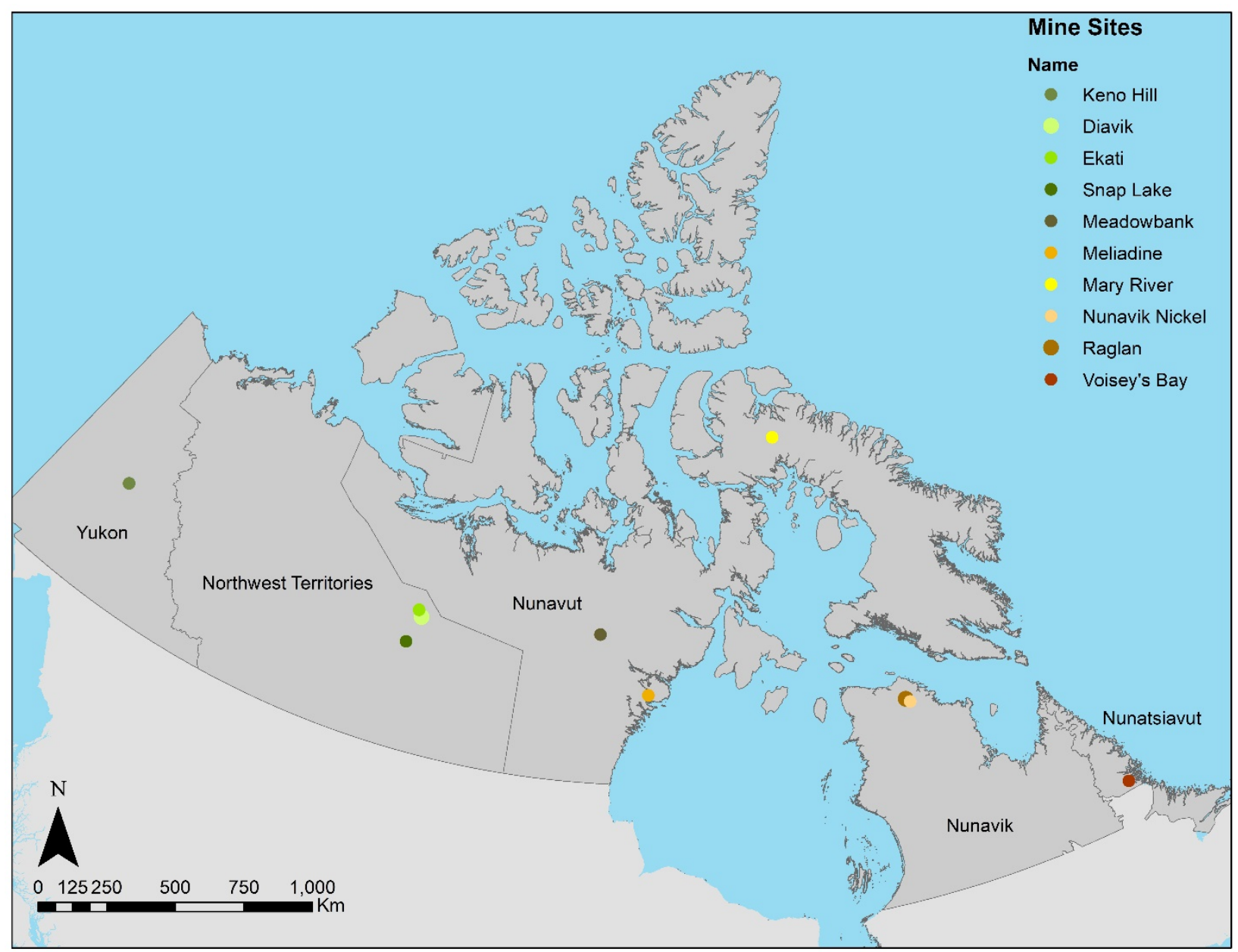

Figure 1: Map of the study area showing the locations of mine sites whose closure plans were collected and analyzed for this paper. Map produced in ArcGIS 10.7.1 using Statistics Canada (2016) data and contains information licensed under the Open Government License - Canada.

Table 1: Northern mine sites whose closure plans were collected and analysed.

$\begin{array}{llllll}\text { Mine Site } & \begin{array}{l}\text { Operating } \\ \text { company }\end{array} & \begin{array}{l}\text { Version } \\ \text { year }^{1}\end{array} & \begin{array}{l}\text { Location } \\ \text { of site }\end{array} & \begin{array}{l}\text { Primary } \\ \text { mineral }\end{array} & \begin{array}{l}\text { Consulted Indigenous group(s) } \\ \text { and organization(s) }\end{array}\end{array}$

\begin{tabular}{|c|c|c|c|c|c|}
\hline $\begin{array}{l}\text { Keno Hill } \\
\text { Mine } \\
\text { Operations }\end{array}$ & Alexco & 2018 & Yukon & Silver & $\begin{array}{l}\text { First Nation of Nacho Nyak Dun } \\
\text { (FNNND) }\end{array}$ \\
\hline $\begin{array}{l}\text { Diavik } \\
\text { Diamond } \\
\text { Mine }\end{array}$ & $\begin{array}{l}\text { Diavik } \\
\text { Diamond } \\
\text { Mines }\end{array}$ & 2017 & NWT & Diamond & $\begin{array}{l}\text { Kitikmeot Inuit Association; Lutsel } \\
\text { K'e Dene First Nation; North Slave } \\
\text { Métis Alliance; Tł̣chǫ Government; } \\
\text { Yellowknives Dene First Nation }\end{array}$ \\
\hline $\begin{array}{l}\text { Ekati } \\
\text { Diamond } \\
\text { Mine }\end{array}$ & $\begin{array}{l}\text { Dominion } \\
\text { Diamond } \\
\text { Mines }\end{array}$ & 2018 & NWT & Diamond & $\begin{array}{l}\text { Tłı̨cho Government; The hamlet of } \\
\text { Kugluktuk and Kitikmeot Inuit } \\
\text { Association; Yellowknives Dene } \\
\text { First Nation; Lutsel K’e Dene First } \\
\text { Nation; North Slave Métis Alliance; } \\
\text { Deninu Kue First Nation; Fort } \\
\text { Resolution Métis Council }\end{array}$ \\
\hline
\end{tabular}




\begin{tabular}{|c|c|c|c|c|c|}
\hline $\begin{array}{l}\text { Snap Lake } \\
\text { Mine }\end{array}$ & De Beers & 2019 & NWT & Diamond & $\begin{array}{l}\text { Tłlıcho Government; Yellowknives } \\
\text { Dene First Nation; Lutsel K’e Dene } \\
\text { First Nation; North Slave Métis } \\
\text { Alliance; }\end{array}$ \\
\hline $\begin{array}{l}\text { Meadowbank } \\
\text { Gold Project }\end{array}$ & $\begin{array}{l}\text { Agnico } \\
\text { Eagle }\end{array}$ & 2014 & Nunavut & Gold & Kivalliq Inuit Association \\
\hline $\begin{array}{l}\text { Meliadine } \\
\text { Gold Project }\end{array}$ & $\begin{array}{l}\text { Agnico } \\
\text { Eagle }\end{array}$ & 2015 & Nunavut & Gold & Kivalliq Inuit Association \\
\hline $\begin{array}{l}\text { Mary River } \\
\text { Project }\end{array}$ & $\begin{array}{l}\text { Baffinland } \\
\text { Iron Mines }\end{array}$ & 2018 & Nunavut & Iron & Qikiqtani Inuit Association \\
\hline Raglan Mine & $\begin{array}{l}\text { Raglan } \\
\text { Mine }\end{array}$ & 2019 & Nunavik & Nickel & $\begin{array}{l}\text { Salluit Land Holdings; } \\
\text { Kangiqsujuaq Land Holdings; } \\
\text { Makivik Corporation }\end{array}$ \\
\hline $\begin{array}{l}\text { Nunavik } \\
\text { Nickel }\end{array}$ & $\begin{array}{l}\text { Canadian } \\
\text { Royalties }\end{array}$ & $\begin{array}{l}2016 / \\
2019^{2}\end{array}$ & Nunavik & Nickel & $\begin{array}{l}\text { Salluit Land Holdings; } \\
\text { Kangiqsujuaq Land Holdings; } \\
\text { Municipality of Puvirnituq; } \\
\text { Makivik Corporation }\end{array}$ \\
\hline Voisey’s Bay & Vale & 2016 & Nunatsiavut & $\begin{array}{l}\text { Nickel; } \\
\text { copper }\end{array}$ & $\begin{array}{l}\text { Innu Nation; Nunatsiavut } \\
\text { Government }\end{array}$ \\
\hline
\end{tabular}

The methods used for this analysis were adapted from literature on document analysis and systematic reviews (e.g., Bowen, 2009; Flick, 2014; Haddaway et al., 2015). These kinds of analyses are flexible tools for understanding gaps, overlaps, and patterns across multiple instances of a type of document (Zou and Thomalla, 2010), in this case mine closure plans. Document analysis generally follows a similar set of steps, including: developing research questions, developing document search criteria and collection methods, coding text into categories appropriate to the research questions, and interpreting, synthesizing, and describing the data (Flick, 2014; Zou and Thomalla, 2010).

Guidance was also taken from Larsen, Österlin, and Guia (2018), who conducted a comparison of impact assessments from mine companies. These authors developed a framework flexible enough to account for the high degree of variability between the impact assessments (Larsen et al., 2018). Similarly, mine closure plans vary considerably in organization, issues addressed, and the collection and application of community knowledge. Therefore, we initially developed broad, open-ended categories for text to be sorted into, along with questions relating to their documentation in closure plans (see Table 2). These three categories are: (1) methods for community engagement; (2) use of community knowledge; and (3) socio-economic impacts of closure.

Table 2: Analytical framework for the review and comparison of mine closure plans.

\begin{tabular}{ll}
\hline Category & Question \\
\hline $\begin{array}{l}\text { Methods for } \\
\text { community } \\
\text { engagement }\end{array}$ & Does the closure plan explain how and when communities are engaged? \\
\cline { 2 - 2 } & $\begin{array}{l}\text { Does the closure plan include what the outcomes were of engagement } \\
\text { activities? }\end{array}$ \\
\hline $\begin{array}{l}\text { Are engagement activities specific to closure planning, or to mine } \\
\text { operations more generally? }\end{array}$ \\
\hline
\end{tabular}




\begin{tabular}{|c|c|}
\hline \multirow{4}{*}{$\begin{array}{l}\text { Use of community } \\
\text { knowledge }\end{array}$} & Where in the closure plan is TK/IQ used? In reference to what topics? \\
\hline & $\begin{array}{l}\text { Does the closure plan clearly demonstrate how community concerns are } \\
\text { being addressed? }\end{array}$ \\
\hline & Is it clear how community input has influenced the closure plan? \\
\hline & $\begin{array}{l}\text { Does the community knowledge refer specifically to aspects of mine } \\
\text { closure, or mine operations more generally? }\end{array}$ \\
\hline \multirow[t]{5}{*}{$\begin{array}{l}\text { Socio-economic } \\
\text { impacts of closure }\end{array}$} & $\begin{array}{l}\text { Does the closure plan acknowledge the possible negative socio-economic } \\
\text { impacts of closure? }\end{array}$ \\
\hline & What kinds of negative impacts are acknowledged? \\
\hline & $\begin{array}{l}\text { Does the closure plan present clear plans for mitigating negative socio- } \\
\text { economic impacts? }\end{array}$ \\
\hline & When are mitigation strategies to begin and end? \\
\hline & Will there be post-closure socio-economic monitoring? \\
\hline
\end{tabular}

The term 'community knowledge' in the context of this research includes the various forms of expertise, stories, and values that come from Northern and Indigenous communities. This includes the many distinct forms of Traditional Knowledge (TK), Indigenous Knowledge (IK), and Inuit Qaujimajatuqangit (IQ), the cumulative body of cultural and ecological knowledge, practices, and values that are generated and maintained by Indigenous communities (Berkes, 2012; Tester and Irniq, 2008; Todd, 2014). It also includes the more general concerns, questions, priorities, and desires that Northern communities have concerning mineral development, mine closure, and their own futures. The broad term 'community knowledge' is not meant to erase the distinctions between different ways of knowing, but instead is meant to be an inclusive short form for the variety of knowledge systems and perspectives that exist across this geographical region, and to distinguish them from the formalized, technical expertise associated with Western science-informed resource management (Haalboom, 2016).

Coding involved the careful review of each document from start to finish, including appendices, and sorting data into the appropriate category in an Excel spreadsheet. Sentences, phrases, tables, and paragraphs that were relevant to each category were copied into individual cells under each category (community engagement methods, use of community knowledge, or socio-economic impacts). Once this was completed for all ten closure plans, the text under each category was re-read several times and any patterns or noteworthy results summarized. These summaries were then compared between the documents.

Qualitative data interpretation focused on understanding the definitions, meanings, and processes revealed in the text (Altheide and Schneider, 2012). Like Larsen et al. (2018), this examination is not meant to determine whether or not information in closure plans is factual. Instead, it is meant to determine how particular mine companies articulate and plan for community-engaged, socio-economic mine closure. Furthermore, this examination did not produce quantitative data or counts of particular words or phrases. Two closure plans can theoretically have an identical number of individual sentences with the same number of individual words in each sentence describing a particular topic, but they would still not be equal because the meaning behind each word used, and how those words contribute to larger narratives, would differ. Thus, a quantitative approach would not produce useful data. Instead, we explore the meanings and narratives in the closure plans, and how they envision a particular future for the site, the region, and the affected communities. 


\section{Results}

\subsection{Documentation of community engagement}

Mine closure plans across Northern Canada tend to use imprecise language to describe the methods used for engaging with and learning from affected communities. Mines operating in the NWT tend to have more informative descriptions than those from other territories/regions. Nunatsiavut and Nunavik closure plans are especially lacking in this area. Where descriptions of community engagement methods do exist, they tend to suffer from two problems. First, explanations do not necessarily describe community engagement that occurred for closure planning specifically, but instead may refer to engagement activities pertaining to mine development or operations. Second, community engagement might only be spoken about in the future tense while failing to document previous or ongoing engagement for closure planning.

All ten closure plans reviewed varied in their descriptions of engagement with affected stakeholders and communities. Some plans contain no mention of impacted communities at all (e.g.: Raglan and Nunavik Nickel in Nunavik); others have relatively clear descriptions of engagement activities and their outcomes (e.g.: Ekati and Diavik in the NWT), although vague statements are present to some degree across all ten documents. Many of the plans make references to the importance of engaging with Indigenous communities, but without clearly articulating their strategies and outcomes. The Keno Hill (Yukon) closure plan, for example, states that the company recognizes the importance of creating a plan that is developed in partnership with Crown-Indigenous Relations and Northern Development Canada (CIRNAC, formerly Indigenous and Northern Affairs Canada), Yukon Government, and First Nation of Nacho Nyak Dun (FNNND). The plan references the company's relationship with FNNND, which "provides for significant consultation and collaboration on closure objectives and final options" (Alexco Resource Corp, 2018, p. 8). The plan is, however, silent on what "significant consultation and collaboration" means, how that will be achieved, how success will be measured, or how input from FNNND was obtained and integrated into the closure plan. The Voisey's Bay (Nunatsiavut) closure plan is similarly limited. In one of the few references to impacted communities, the company states only that it will "provide the Closure Plan to the Innu Nation and the Nunatsiavut Government for review as per the Aboriginal Consultation Guidelines for Regulatory Approval Applications” (Vale Newfoundland and Labrador, 2016, p. 5) and refer to the existence of "mechanisms established during construction and operations" that allow for review and feedback (p. 35). The Meliadine (Nunavut) closure plan offers a final example of this vague language, explaining that the company will "consider community land use expectations and traditional knowledge in the closure planning" and that "community engagement will continue to be implemented” (Agnico Eagle Mines, 2015, p. 7).

Where detailed descriptions of community engagement do exist, it is not always clear if it related to closure specifically, and not other phases of the mine's lifecycle. For example, the Ekati (NWT) closure plan contains details about the incorporation of Traditional Knowledge into wildlife monitoring and other similar programs. While this is an important aspect of Indigenous community engagement, it is not clear if these programs will continue after the mine ceases operations and enters closure and remediation. The Keno Hill, Meliadine, and Snap Lake closure plans all have similar examples of this uncertainty around post-closure engagement. The Keno Hill closure plan explains that "consultation and engagement will include a variety of topics and activities within the [Keno Hill Silver District], including permitting of new mines, development 
of the Keno District Closure Plan or general updates” (Alexco Resource Corp, 2018). In other words, consultation that does happen may not necessarily be specific to mine closure planning. Agnico-Eagle’s Meliadine mine provides another example of generic references to community engagement:

Development plans and potential impacts and benefits resulting from the proposed Project have been presented on an ongoing basis to the general public, community organizations, community leaders, businesses, and government. The feedback obtained from this engagement activity was incorporated in the Project planning to optimize the Project from an environmental and socio- economic point of view, including costs and operability. (Agnico Eagle Mines, 2015)

In some cases, community engagement is only discussed in the future tense. Closure plans will explain how community engagement is going to happen in the future, while neglecting to explain if it has already occurred or been incorporated into the closure plan. One example is the Mary River (Nunavut) closure plan. Mary River is not a new mine--it began operations in 2014. Yet the mine closure plan makes many references to a Mine Closure Working Group that is in development but not yet established or currently contributing to closure planning in any way. The Mary River closure plan also lists a set of topics that the company intends to discuss and receive feedback on from community members, including closure objectives and criteria, additional research activities, and the transfer of infrastructure ownership but there is no clear timetable outlined for this engagement. When any of these goals and requirements will be met is unclear, and describing future community engagement does little to provide insight into what communities' needs, priorities, and concerns have been for the four years between the opening of the mine and the submission of this closure plan.

The Ekati and Diavik diamond mines offer the best examples of how companies can explain their community engagement methods in enough detail to allow reviewers to understand community participation and its incorporation into the closure plan. Both closure plans have relatively detailed descriptions of engagement activities that have already occurred, what issues community members have raised, and how different Traditional Knowledge working groups and Elders have contributed to closure planning. The Ekati closure plan references a Traditional Knowledge Management Framework which “describes protocols for collecting, storing, and managing TK" and "outlines how Dominion will use TK in environmental decisions for the Ekati mine” (Dominion Diamond Mines, 2018). The Diavik closure plan contains a brief history of community engagement and outlines the demographics that make up their Traditional Knowledge Panel, which has men, women, Elders, and youth. The documentation is clear in how this panel contributes to closure, explaining that it is "a body to facilitate appropriate and meaningful accommodation of TK in the planning and review of mine closure options" (Diavik Diamond Mines, 2017). Diavik's closure plan also outlines an engagement strategy developed with input and feedback from community members, noting exactly who will be consulted and how that consultation will happen. Finally, both the Ekati and Diavik closure plans include detailed research plans in their appendices to address remaining uncertainties. These research plans are valuable for both tracking the progress of refining and improving the closure plan over time and acknowledging knowledge gaps. Where other closure plans often shy away from uncertainty and present information as if it is final and complete, the Ekati and Diavik closure 
plans are transparent about the uncertainties surrounding closure and remediation, which then permits them to create plans for filling gaps in knowledge.

\subsection{Use of community knowledge}

As with documentation related to community engagement methods, there is significant variability in how mine closure plans integrate community knowledge. For most of the closure plans, community knowledge is either not explicitly used or acknowledged at all, or it is only referenced generically. Neither mine in Nunavik, Raglan and Nunavik Nickel, make mention of community knowledge in their closure plans. The Meliadine plan states only that local communities' "inputs have been considered in the preparation of this CRP” (Agnico Eagle Mines, 2015), but without explanation of how or where in the document.

In many plans, not only is it unclear how such community review mechanisms address closure and remediation, it is also unclear what 'consideration for traditional knowledge holders' means. The Meadowbank closure plan does contain clear examples of how the company is addressing community concerns, and it states that Traditional Knowledge was used in the summaries of the atmospheric, physical, chemical, biological, and social environments. However, the closure plan often explains that Traditional Knowledge was "recorded" or "documented" or "used" without explaining how and where, or whether this information was gathered specifically for closure planning or as part of other consultation processes. One of their closure objectives is a "final landscape guided by pre-development conditions and traditional knowledge” (Agnico Eagle Mines, 2014, p. 3) with no details on how success would be measured. Such vague statements are common. Without demonstrating how community knowledge is being applied to closure, general references to its existence do little to practically improve closure planning.

The Snap Lake closure plan provides an instructive example of how community knowledge may be documented in the closure plan without necessarily being meaningfully incorporated. The closure plan itself contains almost no references to community influence on the closure plan. However, a 321-page appendix (which is not contained within the same document and must be located separately on the public registry), simply titled 'Appendix C Engagement,' documents all closure-specific community knowledge and government questions and recommendations from 2011 to 2019. Within these 321 pages is a 29-page table that lists Traditional Knowledge input related to closure. This is an overwhelming amount of information that is not organized or synthesized in a way that makes it useful or applicable to the closure plan itself. The body of the plan makes few references to the appendix, and none that point to any specific items in the 321-page appendix. Table 2.2 in the closure plan has a list of "selected engagement" activities taken from the engagement record, but no specific outcomes are listed, just descriptions of topics discussed and dates.

Where closure plans do clearly reference community knowledge, it is most often limited to descriptions of places and ecosystems, and/or concerns about animal and fish species. This information is contained within sections dedicated to community engagement (usually at the beginning of the document) or sections specifically related to wildlife impacts. Rarely do any of the closure plans engage with any form of community knowledge related to the more technical or future-oriented aspects of closure and remediation. This is not to undervalue the importance of using knowledge from communities to understand the mine's ecological and social context. However, it appears that companies (or the consultants they hire to draft closure plans) are 
operating with the assumption that communities only have valuable information to provide about the natural environment, not other aspects of closure and remediation. Although these documents are essentially plans for the future, community knowledge is routinely limited to descriptions of past or current conditions. Even in the best examples of community-engaged closure plans, it is less clear how community knowledge is incorporated into the remediation of pits and tunnels, management of tailings and waste rock, mitigation of contaminants, and post-closure wildlife and socio-economic monitoring. These results echo those reported by Sandlos and Keeling (Sandlos and Keeling, 2016) on the remediation project for the abandoned Giant Mine in the NWT. They argue that the planning and assessment process for this major remediation project confined IK to apolitical information about traditional harvesting: "almost nowhere did the report mandate or even mention the ways the TK, and the values embedded in such knowledge systems, might inform technical aspects of the project such as arsenic storage or surface remediation” (p. 285). In closure planning, it is engineers and professional scientists who have the privilege and power to construct the future, rather than communities.

A few notable exceptions show promise for better engagement with and use of community knowledge in closure planning. Closure plans from the NWT, particularly for the Ekati and Diavik mines, more clearly articulate how they are utilizing community knowledge and demonstrate how the company is responding to community needs, concerns, and requests. The Ekati closure plan gives a number of clear examples distributed throughout the closure plan where community concerns are summarized and addressed, for instance:

Community visits in mid-2018 yielded further feedback on the WRSA piles. Many noted the sensitivity of caribou to large cobbles and boulders, and the potential for very coarse substrate on the piles to result in potential for injury. A common suggestion was to ensure that a fine-grained material be used to cover the waste rock storage piles to avoid this potential. It was also recommended that ramps be of an appropriate slope to allow caribou easy access on and off of piles. (Dominion Diamond Mines, 2018)

Community members have suggested that studies be undertaken to determine what plant species can be effectively grown on kimberlite, and that the community be involved. (Dominion Diamond Mines, 2018)

While documented concerns often emerge from community members' prioritization of ecological health, the number of different topics addressed is higher than most other closure plans. In the examples above, the closure plan clearly demonstrates that community members were able to provide input to waste rock pile covers and the possibilities for kimberlite remediation.

The Diavik closure plan similarly contains a number of examples of community knowledge being clearly documented and addressed. It explains that the mine's TK Panel evaluated re-vegetation plans and contributed knowledge about pre-mining plant and wildlife baselines. The plan lists several community priorities for closure, including the significance of land and water quality, potential employment and business opportunities for Northern peoples, compensation for land and water use, the need for regular consultation, and minimizing the overall footprint of the mine site. It also includes design principles identified by workshop participants, such as consolidating the mine site and where to put processed kimberlite. Like the Ekati closure plan, community concerns, priorities, and expertise are not limited to one or two 
sections dedicated to community engagement or wildlife descriptions, but instead are integrated throughout the document and include a variety of topics.

\subsection{Socio-economic impacts}

As with community engagement and community knowledge, the incorporation of socioeconomic objectives into these closure plans is typically cursory and/or poorly documented. While industry guidelines and best practices increasingly emphasize the need to address the social and economic impacts of mine closure, these plans lack any common understanding, acknowledgement, or standard practice for mitigating these impacts. The Snap Lake, Voisey's Bay, and Nunavik Nickel closure plans either do not mention negative socio-economic impacts or simply state that there will be none. The Ekati closure plan only mentions a permanent visual change to the landscape in relation to cultural impacts. In the Meliadine closure plan, one of the goals listed for closure is to "help protect traditional values" and "mitigate socio-economic impacts in the area where the mine is located following decommissioning and closure as practically possible” (Agnico Eagle Mines, 2015). These goals and impacts remain undefined in the document. The Raglan mine closure plan states multiple times that a particular closure method or strategy was chosen based on "environmental, societal and economic performance" (Raglan Mine, 2019), but these criteria remain undefined.

When closure plans acknowledge negative impacts, they are often limited in scope or not related to closure. The Diavik plan claims that information about socio-economic impacts is included in an appendix titled "Site-Specific Risk-Based Closure Criteria Phase I Report," but upon review it is clear that these impacts are limited to the potential for contaminants to be found in country foods. The Meadowbank closure plan also limits discussion of health risks to country food consumption. In other cases, the impacts addressed are limited to job loss and the potential loss of archaeological sites. For instance, as the sole example of a possible negative socioeconomic impact, the Nunavik Nickel closure plan mentions strategies for avoiding damaging archaeological sites and refers readers to the original environmental impact assessment. Similarly, in describing possible residual negative impacts on the human and physical environment, the Snap Lake closure plan makes several references to the effects of construction and operations and cites the original environmental assessment report from 2002 as evidence that these impacts will not extend beyond those phases.

In some cases, even when negative socio-economic impacts are acknowledged they are deemed not significant or outweighed by the apparently more significant positive benefits experienced during operations. The Mary River closure plan considers that if an individual is likely to experience both a negative and a positive impact, then the negative impact is deemed not significant - therefore a mitigation strategy is not required. For example, the plan concludes that educational and training opportunities for employees and community members during operations will offset the negative effects of job-loss at closure. The plan also states that, overall, "the potential for beneficial outcomes is equally or more highly anticipated than the potential for negative effects" (Baffinland Iron Mines, 2018). This ignores the considerable evidence for the opposite effect: that the economic and employment benefits of mining in remote regions are often (though not always) short-lived, unevenly distributed, and outweighed by the longer-term negative impacts of closure (Bainton and Holcombe, 2018; Bowes-Lyon et al., 2009; Buell, 2006; Lawrie et al., 2011; Rodon and Lévesque, 2015; Wilson, 2004). 
In general, concrete plans for mitigating negative socio-economic impacts are rare in these closure plans. The Raglan, Nunavik Nickel, Voisey’s Bay, and Snap Lake closure plans present no plans whatsoever for mitigating negative regional socio-economic impacts. Others make general statements about this issue but lack concrete strategies. One objective in the Keno Hill closure plan is to "maximize First nation, local, and Yukon socio-economic benefits" (Alexco Resource Corp, 2018). This is the only mention of socio-economic benefits in the closure plan, and there is no explanation for what 'maximize' means in this context or how it will be achieved. Similarly, the Diavik closure plan also includes an objective to "maximize northern business opportunities during operations and closure" and "develop northern capacities during operations and closure for the benefit of the north, post-closure” (Diavik Diamond Mines, 2017) but with no real plan of action. The Meadowbank closure plan also states the company's intention to "maximize the benefits of the Project for all parties involved while minimizing or eliminating any negative impacts or long-term influences on the environment and local communities” (Agnico Eagle Mines, 2014) without further explanation. Some closure plans briefly mention the transfer of infrastructure to communities after closure, but with no real plans for execution. Without clear strategies for this transfer companies risk leaving communities with infrastructure that they are unable to operate and maintain (Laurencont et al., 2019; Roberts et al., 2000; Xavier et al., 2015).

A number of closure plans contend the socio-economic impacts will be investigated closer to, during, or after closure. For instance, the Meliadine and Mary River closure plans explain that data collected during operations will contribute to post-closure monitoring activities, but include no details on how the socio-economic aspects of closure are being planned for and mitigated now. The Meadowbank closure plan states that "post-reclamation risks to human and environmental health will be identified and evaluated closer to mine closure, once the final closure designs are determined” (Agnico Eagle Mines, 2014). Yet this plan was published in 2014, when the expected closure date of the mine site was only five years later in 2019. This means that the next and final closure plan for Meadowbank will be the first to include any discussion of human risks, which is far too late for local, regional, and territorial authorities to assess. In contrast to this scant coverage of socio-economic closure issues, Rixen and Blangy (2016) found that local residents near Meadowbank have concerns about community violence, stress, and food security when the mine closes and suggest strategies for improving community resilience. Based on its closure plan, the company has not engaged with the local knowledge and concerns about closure planning that exist within this community. This deferral of socioeconomic closure planning directly contradicts industry best practice guidelines like those published by the International Council on Mining and Metals, which suggest that closure planning must integrate social, economic, and cultural considerations early in the mine's life, in order to have the time to develop an adequate knowledge base and prepare for the complexities of these aspects of closure (International Council on Mining \& Metals, 2019a).

\section{Discussion}

Mine closure plans across Northern Canada are highly variable documents with often generic references to local and Indigenous community engagement, few explicit examples of community knowledge being incorporated into closure planning, and weak planning for the socio-economic and cultural impacts of closure. How poorly a closure plan addresses these issues differs between mine sites, although there appears to be a significant difference between 
closure plans from the NWT and Nunavut and those from Yukon, Nunavik, and Nunatsiavut. The latter tend to entirely neglect the socio-economic impacts of closure and contain more illdefined language compared to closure plans from the NWT and Nunavut.

Different territorial and provincial regulatory regimes likely account for some of this variability. As noted in Section 2, mine closure policies, regulations, and guidelines vary across these jurisdictions. Policies in the NWT and to a lesser extent Nunavut provide more thorough guidelines for addressing the socio-economic aspects of closure and place a heavier emphasis on collecting and incorporating community knowledge in closure plans. Guidance and policy documents from the Nunavut Impact Review Board (NIRB) and Nunavut Water Board (NWB) make connections between mine closure and potential impacts to cultural sites, employment, community wellness, community infrastructure, and human health (Nunavut Impact Review Board and Nunavut Water Board, 2012), and both organizations mandate community consultation throughout a mine's life. The Mackenzie Valley Land and Water Board (MVLWB) requires proponents in the NWT to "consider factors such as risk acceptability, public perception of risk, socio-economic impacts, benefits, and technical feasibility” in their closure plans (Mackenzie Valley Land and Water Board, 2013), and their guidelines for closure and reclamation have detailed requirements for community engagement and the integration of Traditional Knowledge. The results are closure plans that more clearly address community concerns and acknowledge a wider (though by no means complete) range of negative impacts. Closure plans for mines in NWT and Nunavut were more likely to address a wider scope of issues and more clearly engage with community knowledge.

By contrast, plans from Yukon, Nunavik, and Nunatsiavut lacked detail and sometimes entirely neglected all three elements examined for this study. Policy guidance on mine closure from these jurisdictions makes few connections between closure planning, community engagement, and socio-economic impacts. In Newfoundland and Labrador, projects are "evaluated for [their] bio-physical and socio-economic impacts" during the environmental assessment phase (Newfoundland and Labrador, 2010), but no further detail is provided and no connections are made between socio-economic impacts and closure in mining guidelines or environmental assessment regulations. The Québec government closure guidelines (which apply to the Nunavik territory) state that remediation must meet social objectives, but provide no definition or criteria (Ministère de l'Énergie et des Ressources naturelles, 2017). Nunavik does have several regional authorities (the Kativik Environmental Advisory Committee, Kativik Environmental Quality Commission, and Makivik Corporation) responsible for facilitating public engagement and holding companies accountable to Nunavik Inuit, but the Nunavik Inuit Mining Policy only requires social impact studies to be carried out for mineral exploration and operations, not closure (Makivik Corporation, 2014). The Government of Yukon (Government of Yukon, 2006) emphasizes the need for remediation strategies that "will provide economic benefits to local communities and First Nations” (p. 9). All of these statements are generic and open to a wide range of interpretations--similar to the language used in the closure plans themselves.

Variations in policy cannot account for all of the differences found in these closure plans, however, and even the most robust closure regulations leave significant gaps. The Mary River closure plan, for example, includes a terms and conditions concordance table that lists the NIRB's closure conditions for the company's water license (Baffinland Iron Mines, 2018). A 
wide range of issues are included, from concerns about the marine environment to noise pollution, and more social and economic concerns about demographics, livelihood, and wellbeing. Most of the conditions for the socio-economic aspects of closure can be summarized as asking the company to engage with specific community groups and regional organizations to monitor and mitigate socio-economic impacts. While this is not a clear plan in itself, and the Mary River closure plan overall does a poor job addressing the socio-economic aspects of closure, the conditions in this table are an encouraging inclusion that points to the possibility of communities being able to guide closure planning when adequate regulatory frameworks exist. However, the wording used for socio-economic and cultural conditions in this table is notably weaker than the wording used for conditions related to the natural environment despite regulations in Nunavut being stricter than most other territories/provinces. The word 'encouraged' is only used in the table when discussing issues related to population demographics, livelihoods, economic development, human health and well-being, community infrastructure, culture, and socio-economic impacts. For other topics, like the marine environment and wildlife monitoring, stronger language is used, such as 'shall ensure,' 'shall review,' 'shall maintain,' and 'shall meet or exceed.'

Within the same territory or region, closure plans vary considerably in how effectively they address community knowledge and socio-economic impacts. The Ekati and Diavik closure plans contain many positive examples, whereas the Snap Lake closure plan (also in the NWT) only nominally meets territorial requirements by including a lengthy community engagement report in its appendix, without clear indications of how this information is incorporated into the plan. In Nunavut, the Meliadine and Meadowbank closure plans hardly mention potential negative socio-economic impacts, while the Mary River closure plan at least acknowledges a wider scope of issues. These variations indicate that, even where policies and guidelines are more thorough and directive, companies can interpret and address those policies in ways that suit them. In effect, the quality of a company's closure plan depends on its willingness to go above and beyond minimal requirements and honour the spirit of territorial guidelines as well as its relationship to local communities.

\section{Conclusion}

Successful strategies for involving Indigenous communities in mine closure planning remain limited and mostly undocumented in academic literature and, as this research shows, in industry documents. For mine closure to be successful and not repeat past failures, companies must work to understand and apply community expertise. Goals and outcomes for closure must engage local values, needs, priorities, and visions for the future (Xavier et al., 2015). A detailed analysis of Northern Canadian closure plans allowed us to examine how government policy and industry practices are coming together in this region to create particular futures for mine sites (and their affected communities). We asked how these closure plans, the official and detailed instructions for the closure of a mine site, are utilizing community knowledge, describing their community engagement strategies, and addressing the social dimensions of closure and remediation.

In general, our results reaffirmed observations made elsewhere: mine closure focuses heavily on addressing technical issues, while more complex social, cultural, and historical challenges are not well understood or left out the scope of the planning process (Bainton and 
Holcombe, 2018; Beckett and Keeling, 2019; Cohen, 2017). Socio-economic impacts are poorly addressed and, in many cases, go unacknowledged altogether in these documents. If negative impacts are listed, they are often too limited in scope or they are related more to the earlier phases of the mine's life, not closure directly. In other cases, companies appear to assume that the negative impacts of closure are offset by positive impacts experienced during operations, despite closure having unique impacts that require specialized mitigation strategies. Overall, few plans contain concrete strategies for mitigation, making any acknowledgements of negative impacts ineffective in improving the material conditions of communities after closure.

Similarly, the community engagement methods for closure planning are poorly documented. These methods are critical pieces of information for evaluating the quality of a closure plan, as they provide insight into how well the company understands the needs and priorities of the communities to whom they are accountable. In some cases, community engagement is only spoken about in the future tense, regardless of how close the mine site is to its expected closure date. Where past community engagement is described, outcomes are rarely included, making it impossible to evaluate whether or not a company has addressed community concerns. The contents of these closure plans do not appear to align with mine closure guidelines that stress the importance of engaging early with affected communities (International Council on Mining \& Metals, 2019a; The Mining Association of Canada, 2008). These recommendations are particularly important given the volatile nature of mineral markets and histories of abrupt closures in Northern Canada (Laurence, 2006; Sandlos and Keeling, 2016) - mine companies may not have the time they think they do to engage with communities and develop (and execute) long-term, socially and culturally appropriate closure strategies.

The application of community expertise gained through community engagement can create space for local contributions to the goals, criteria, and outcomes of closure. This is especially important in the North where Indigenous land use, sovereignty, and self-determination can be negatively impacted by large-scale mining developments and the long-term environmental impacts of improper remediation (Rodon, 2018). Yet in spite of growing participation and consultation in mineral development and environmental assessment, Indigenous communities remain largely excluded from mine closure planning. In most of these documents, there are no clear indications of how or whether community knowledge was incorporated in the plan, nor is local knowledge cited as a source of information related to closure strategies, beyond descriptions of the natural environment.

These findings provide potential lessons that the governments of Yukon, Québec/Nunavik, and Nunatsiavut/Newfoundland and Labrador can learn from the NWT and Nunavut. Closure guidelines and regulations must explicitly demand that closure plans account for more than just the removal of infrastructure and physical remediation of pits and waste piles. From an early stage, closure plans must clearly outline strategies for community engagement and plan for the sustainability of affected communities. Guidelines from governments and regional authorities must establish clear requirements between community engagement, socio-economic impacts, and closure. While some mining acts and resource policies have specific requirements for community engagement or addressing socio-economic impacts, these are rarely specific to the closure phase. This allows companies to neglect these critical elements in closure planning. Furthermore, even the best examples of closure governance have room for improvement, to provide more specific and prescriptive guidance for closure planning and limit variation in 
company closure plans. Finally, while the particular history and geographical characteristics of the region make the impacts felt by Northern communities unique, the insights gained from this research are applicable globally_where many of these same mining companies operate. Including local voices, grounding closure planning in the socio-economic context of mine operations, and setting clear, measurable goals for mitigating negative impacts are best practices that all mines and mining communities will benefit from.

\section{Acknowledgements}

The authors would like to thank the National Sciences and Engineering Research Council of Canada network, Towards Environmentally Responsible Resource Extraction (TERRE-NET), and the Social Sciences and Humanities Research Council of Canada for generously funding this research. Parts of this paper are adapted with permission of the authors from Caitlynn Beckett, Elizabeth Dowdell, Miranda Monosky, and Arn Keeling, "Integrating socio-economic objectives for mine closure and remediation into impact assessment in Canada,” unpublished Knowledge Synthesis report for the Social Sciences and Humanities Research Council and Canadian Environmental Assessment Agency, 2019. The authors would also like to thank Caitlynn Beckett and Aimee Pugsley for their thoughtful comments on earlier versions of this paper, Isabella Richmond for her GIS work, and Arielle Frenette for translating essential documents.

Funding: This work was supported by the National Sciences and Engineering Research Council network, Towards Environmentally Responsible Resource Extraction (TERRE-NET), grant no.479708-2015; and Social Sciences and Humanities Research Council Knowledge Synthesis Grant, no. 872-2019-005. 


\section{References}

Agnico Eagle Mines, 2015. Meliadine Preliminary Closure and Reclamation Plan. https://www.nwb-oen.ca/content/public-registry

Agnico Eagle Mines, 2014. Meadowbank closure plan. https:/www.nwb-oen.ca/content/publicregistry

Alexco Resource Corp, 2018. Reclamation and Closure Plan: Keno District Mine Operations. https://yukon.ca/en/science-and-natural-resources/mining/keno-hill-silver-district-mininglicensing-documents

Ali, S.H., 2003. Mining, the Environment, and Indigenous Development Conflicts, first ed. University of Arizona Press, Tucson.

Altheide, D.L., Schneider, C.J., 2012. Qualitative Media Analysis. SAGE Publications, London, UK.

Archer, K., Bradbury, J., 1992. The life and death of a company town, in: Neil, C., Tykkyläinen, M., Bradbury, J. (Eds.), Coping with Closure: An International Comparison of Mine Town Experiences. Routledge, London; New York, pp. 169-191.

Baffinland Iron Mines, 2018. Mary River Interim Closure and Reclamation Plan. https://www.baffinland.com/media-centre/document-portal/

Bainton, N., Holcombe, S., 2018. A critical review of the social aspects of mine closure. Resour. Policy 59, 468-478. https://doi.org/10.1016/j.resourpol.2018.08.020

Ballard, C., Banks, G., 2003. Resource wars: The anthropology of mining. Annu. Rev. Anthropol. 32, 287-313. https://doi.org/10.1146/annurev.anthro.32.061002.093116

Bebbington, A., 2012. Underground political ecologies: the second Annual Lecture of the Cultural and Political Ecology Specialty Group of the Association of American Geographers. Geoforum 43, 1152-1162. https://doi.org/10.1016/j.geoforum.2012.05.011

Beckett, C., Keeling, A., 2019. Rethinking remediation: mine reclamation, environmental justice, and relations of care. Local Environ. 24, 216-230. https://doi.org/10.1080/13549839.2018.1557127

Berkes, F., 2012. Sacred Ecology: Traditional Ecological Knowledge and Resource Management. Routledge, New York, NY.

Boutet, J.-S., 2014. Opening Ungava to industry: a decentring approach to Indigenous history in subarctic Québec, 1937-54. Cult. Geogr. 21, 79-97. https://doi.org/10.1177/1474474012469761

Bowen, G.A., 2009. Document analysis as a qualitative research method. Qual. Res. J. 9, 27-40. https://doi.org/10.3316/QRJ0902027

Bowes-Lyon, L.-M., Richards, J.P., McGee, T.M., 2009. Socio-Economic Impacts of the Nanisivik and Polaris Mines, Nunavut, Canada, in: Richards, J.P. (Ed.), Mining, Society, and a Sustainable World. Springer, Berlin, pp. 371-396. https://doi.org/10.1007/978-3-64201103-0 
Bradbury, J.H., St-Martin, I., 1983. Winding down in a Quebec mining town: a case study of Schefferville. Can. Geogr. / Le Géographe Can. 27, 128-144. https://doi.org/10.1111/j.1541-0064.1983.tb01468.x

Bradshaw, B., Fidler, C., Wright, A., 2018. Impact and benefit agreements and northern resource governance: What we know and what we still need to figure out. Resour. Sustain. Dev. Arct. 204-218. https://doi.org/10.4324/9781351019101

Buell, M., 2006. Resource Extraction Development and Well-Being in the North: A Scan of the Unique Challenges of Development in Inuit Communities. Ajummginiq Centre, National Aboriginal Health Organization.

Burns, C., Church, J., 2018. Managing the social impacts of mine closure: how companies can better manage the social impacts of mine closure. Can. Min. J. 6, 8-9. https://searchproquest-com.qe2a-proxy.mun.ca/docview/2099846777?accountid=12378.

Caine, K.J., Krogman, N., 2010. Powerful or just plain power-full? A power analysis of impact and benefit agreements in Canada’s North. Organ. Environ. 23, 76-98. https://doi.org/10.1177/1086026609358969

Cameron, E., Levitan, T., 2014. Impact and benefit agreements and the neoliberalization of resource governance and Indigenous-state relations in Northern Canada. Stud. Polit. Econ. 93, 25-52. http://doi.org/10.1080/19187033.2014.11674963

Cohen, T., 2017. Bringing country back? Indigenous aspirations and ecological values in Australian mine-site rehabilitation, in: Jalbert, K., Willow, A., Casagrande, D., Paladino, S. (Eds.), ExtrACTION: Impacts, Engagements and Alternative Futures. Routledge, New York, pp. 137-150.

Costa, S., 2015. Social impacts of mine closure: engaging employees and host communities in planning for closure, in: Fourie, A.B., Tibbett, M., Sawatsky, L., van Zyl, D. (Eds.), British Columbia Mine Reclamation Symposium. UBC, Vancouver, pp. 1-8. https://doi.org/10.14288/1.0305870

Cowan, W.R., Mackasey, W.O., Robertson, J.G.A., 2010. The Policy Framework in Canada for Mine Closure and Management of Long-term Liabilities: A Guidance Document. National Orphaned/Abandoned Mines Initiative.

Dance, A., Monosky, M., Keeling, A., Sandlos, J., 2020. Mine Remediation Policy and Practice in Northern Canada. Forthcoming Resources and Sustainable Development in the Arctic (ReSDA) book chapter.

Diavik Diamond Mines, 2017. Diavik Closure and Reclamation Plan - Version 4.0. https://mvlwb.com/registry/W2015L2-0001

Dominion Diamond Mines, 2018. Ekati Mine Interim Closure and Reclamation Plan. https://mvlwb.com/registry/W2012L2-0001

Edwards, J., Maritz, A., 2019. Social aspects of mine closure: the elephant in the room, in: Fourie, A., Tibbett, M. (Eds.), Proc. 13th Int. Conf. Mine Clos. Australian Center for Geomechanics, Perth, AU, pp. 305-316.

http://doi.org/10.36487/ACG_rep/1915_25_Edwards 
Ellis, S.C., 2004. Meaningful consideration? A review of Traditional Knowledge in environmental decision making. Arctic 58, 66-77. https://doi.org/10.2307/40512668

Flick, U., 2014. The SAGE Handbook of Qualitative Data Analysis. SAGE Publications, London, UK.

Government of Yukon, 2006. Yukon Mine Site Reclamation and Closure Policy. Whitehorse, YK.

Green, H., 2015. “There is no memory of it here”: closure and memory of the Polaris Mine in Resolute Bay 1973-2012, in: Keeling, A., Sandlos, J. (Eds.), Mining and Communities in Northern Canada: History, Politics, and Memory. University of Calgary Press, Calgary.

Haalboom, B., 2016. Pursuing openings and navigating closures for aboriginal knowledges in environmental governance of uranium mining, Saskatchewan, Canada. Extr. Ind. Soc. 3, 1010-1017. https://doi.org/10.1016/j.exis.2016.09.002

Haddaway, N., Woodcock, P., Macura, B., Collins, A., 2015. Making literature reviews more reliable through application of lessons from systematic reviews. Conserv. Biol. 29, 15961605. https://doi.org/10.1111/cobi.12541

Hoadley, E.M., Limpitlaw, D., 2008. Preparation for closure - community engagement and readiness starting with exploration, in: Fourie, A.B., Tibbett, M., Weiersbye, I.M., Dye, P.J. (Eds.), Proc. 13th Int. Conf. Mine Clos. Australian Center for Geomechanics., Johannesburg, SA, pp. 845-851.

Horowitz, L.S., 2015. Culturally articulated neoliberalisation: corporate social responsibility and the capture of Indigenous legitimacy in New Caledonia. Trans. Inst. Br. Geogr. 40, 88-101.

Horowitz, L.S., Keeling, A., Lévesque, F., Rodon, T., Schott, S., Thériault, S., 2018. Indigenous peoples' relationships to large-scale mining in post/colonial contexts. Extr. Ind. Soc. 3, 404414. https://doi.org/10.1016/j.exis.2018.05.004

Howitt, R., 2001. Rethinking Resource Management: Justice, Sustainability and Indigenous Peoples. Routledge, London.

International Council on Mining \& Metals, 2019a. Integrated Mine Closure: Good Practice Guide. London, UK.

International Council on Mining \& Metals, 2019b. Financial concepts for mine closure. London, UK.

Jacka, J.K., 2018. The anthropology of mining: the social and environmental impacts of resource extraction in the mineral age. Annu. Rev. Anthropol. 47, 61-77. https://doi.org/10.1146/annurev-anthro-102317-050156

Kabir, S.Z., Rabbi, F., Chowdhury, M.B., Akbar, D., 2015. A Review of Mine Closure Planning and Practice in Canada and Australia. World Rev. Bus. Res. 3, 140-159

Keeling, A., Sandlos, J., 2015. Mining and Communities in Northern Canada: History, Politics, and Memory. University of Calgary Press, Calgary.

Keeling, A., Sandlos, J., 2009. Environmental justice goes underground? Historical notes from 
Canada's Northern mining frontier. Environ. Justice 3, 117-125.

https://doi.org/10.1089/env.2009.0009

Kendall, G., 1992. Mine closures and worker adjustment: The case of Pine Point, in: Neil, C., Tykkyläinen, M., Bradbury, J. (Eds.), Coping with Closure: An International Comparison of Mine Town Experiences1. Routledge, London; New York, pp. 131-150.

Langhorst, J., Bolton, K., 2017. Reframing the postindustrial: landscapes of extraction between reclamation and reinvention. Chang. Over Time 7, 158-182. https://doi.org/10.1353/cot.2017.0008

Lapalme, L.-A., 2003. The Social Dimension of Sustainable Development and the Mining Industry: A Background Paper. Natural Resources Canada, Ottawa, CA.

Larsen, R.K., Österlin, C., Guia, L., 2018. Do voluntary corporate actions improve cumulative effects assessment? Mining companies' performance on Sami lands. Extr. Ind. Soc. 5, 375383. https://doi.org/10.1016/j.exis.2018.04.003

Laurence, D., 2006. Optimisation of the mine closure process. J. Clean. Prod. 14, 285-298. https://doi.org/10.1016/j.jclepro.2004.04.011

Laurencont, T., Garrood, T., Vidler, P., Fawcett, M., 2019. Social provisioning for mine closure, in: Fourie, A., Tibbett, M. (Eds.), Proc. 13th Int. Conf. Mine Clos. Australian Center for Geomechanics, Perth, AU. https://doi.org/10.36487/ACG_rep/1915_24_Laurencont

Lawrie, M., Tonts, M., Plummer, P., 2011. Boomtowns, resource dependence and socioeconomic well-being. Aust. Geogr. 42, 139-164. https://doi.org/10.1080/00049182.2011.569985

Lim, T.W., 2013. Inuit Encounters with Colonial Capital: Nanisivik - Canada's First High Arctic Mine [Master's thesis, University of British Columbia]. University of British Colombia Library Archives. https://doi.org/10.14288/1.0073541

Mackenzie Valley Land and Water Board, 2013. Guidelines for the closure and reclamation of advanced mineral exploration and mine sites inthe Northwest Territories. Aboriginal Affairs and Northern Development Canada, Yellowknife, NT.

Makivik Corporation, 2014. Nunavik Inuit Mining Policy. Kuujjuaq, QB.

McDonald, P., Mayes, R., Pini, B., 2012. Mining work, family and community: a spatiallyoriented approach to the impact of the Ravensthorpe Nickel Mine closure in remote Australia. J. Ind. Relations 54, 22-40. https://doi.org/10.1177/0022185611432382

McGregor, D., 2013. Toward a paradigm of Indigenous collaboration for geographic research in Canadian environmental and resource management, in: Johnson, J.T., Larsen, S.C. (Eds.), Deeper Sense Of Place: Stories And Journeys Of Indigenous-Academic Collaboration. Oregon State University Press, Corvallis, OR, pp. 157-188.

Ministère de l’Énergie et des Ressources naturelles, 2017. Guidelines for Preparing Mine Closure Plans in Québec. Québec, QC.

Morrison-Saunders, A., 2019. The action is where the social is! The ecosystem services concept 
and other ideas for enhancing stakeholder engagement in integrated mine closure planning. Proc. 13th Int. Conf. Mine Clos. Australian Centre for Geomechanics, Perth, AU, pp. 5-18. https://doi.org/10.36487/acg_rep/1915_02_morrison-saunders

Neil, C., Tykkyläinen, M., Bradbury, J., 1992. Coping with Closure: An International Comparison of Mine Town Experiences. Routledge, London; New York.

Newfoundland and Labrador, 2010. Guidebook to Exploration, Development and Mining in Newfoundland and Labrador.

Nunavut Impact Review Board, Nunavut Water Board, 2012. Detailed Coordinated Process Framework for NIRD Reviews and NWB Licensing.

O’Faircheallaigh, C., 2018. Aboriginal-mining company contractual agreements in Australia and Canada: implications for political autonomy and community development. Can. J. Dev. Stud. 30, 69-86. https://doi.org/10.1080/02255189.2010.9669282

O’Faircheallaigh, C., Lawrence, R., 2019. Mine closure and the Aboriginal estate. Aust. Aborig. Stud. 2019, 65-81.

Papillon, M., Rodon, T., 2017. Proponent-Indigenous agreements and the implementation of the right to free, prior, and informed consent in Canada. Environ. Impact Assess. Rev. 62, 216224. https://doi.org/10.1016/j.eiar.2016.06.009

Parlee, B., 2012. Finding voice in a changing ecological and political landscape - tTraditional Knowledge and resource management in settled and unsettled claim areas of the Northwest Territories, Canada. Aborig. Policy Stud. 2, 56-87. https://doi.org/10.5663/aps.v2i1.17704

St-Laurent, P.G., Billon, P., 2015. Staking claims and shaking hands: impact and benefit agreements as a technology of government in the mining sector. Extr. Ind. Soc. 3, 590-602. https://doi.org/10.1016/j.exis.2015.06.001

Pini, B., Mayes, R., McDonald, P., 2010. The emotional geography of a mine closure: a study of the Ravensthorpe nickel mine in Western Australia. Soc. Cult. Geogr. 11, 559-574. https://doi.org/10.1080/14649365.2010.497850

Raglan Mine, 2019. Raglan Mine Closure Plan.

Rixen, A., Blangy, S., 2016. Life after Meadowbank: exploring gold mine closure scenarios with the residents of Qamini’tuaq (Baker Lake), Nunavut. Extr. Ind. Soc. 3, 297-312. https://doi.org/10.1016/j.exis.2015.09.003

Roberts, S., Veiga, M., Peiter, C., 2000. Overview of Mine-closure and Reclamation in the Americas. UBC, Vancouver.

Rodon, T., 2018. Institutional development and resource development: the case of Canada's Indigenous peoples. Can. J. Dev. Stud. 39, 119-136. https://doi.org/10.1080/02255189.2017.1391069

Rodon, T., Lévesque, F., 2015. Understanding the social and economic impacts of mining development in Inuit communities: experiences with past and present mines in Inuit Nunangat. North. Rev. 41, 13-39. https://doi.org/10.22584/nr41.2015.002 
Sánchez, L.E., Silva-Sánchez, S.S., Neri, A.C., 2014. Guide for mine closure planning, Brazilian Mining Association.

Sandlos, J., Keeling, A., 2016. Aboriginal communities, Traditional Knowledge, and the environmental legacies of extractive development in Canada. Extr. Ind. Soc. 3, 278-287. https://doi.org/10.1016/j.exis.2015.06.005

Sandlos, J., Keeling, A., 2012. Claiming the new North: development and colonialism at the Pine Point Mine, Northwest Territories. Environ. Hist. Camb. 18, 5-34. https://doi.org/10.3197/096734012X13225062753543

Spitz, K., Trudinger, J., 2008. Mining and the Environment: From ore to metal. CRC Press, Boca Raton, FL.

Stacey, J., Naude, A., Hermanus, M., Frankel, P., 2010. The socio-economic aspects of mine closure and sustainable development: Literature overview and lessons for the socioeconomic aspects of closure - Report 1. J. S. Afr. I. Min. Metall. 7, 379-394.

Strambo, C., Aung, M.T., Atteridge, A., 2019. Navigating coal mining closure and societal change: learning from past cases of mining decline, Stockholm Environment Institute. https://www.sei.org/publications/navigating-coal-mining-closure-and-societal-change/

Tester, F.J., Irniq, P., 2008. Inuit Qaujimajatuqangit: social history, politics and the practice of resistance. Arctic 1, 48-61. https://doi.org/10.14430/arctic101

The Mining Association of Canada, 2008. Mine Closure Framework Mine Closure, Towards Sustainable Mining.

Todd, Z., 2014. Fish Pluralities: Human-animal relations and sites of engagement in Paulatuuq, Arctic Canada. Études/Inuit/Studies 38, 217-238.

Tsosie, R., 2015. Indigenous Peoples and the Ethics of Remediation: Redressing the Legacy of Radioactive Contamination for Native Peoples and Native Lands - viewcontent.cgi. St. Cl. J. Int. Law 13, 203-272. https://doi.org/10.7202/1028861ar

Vale Newfoundland and Labrador, 2016. Rehabilitation and Closure Plan: Voisey’s Bay.

Veiga, M.M., Scoble, M., McAllister, M.L., 2001. Mining with communities. Nat. Resour. Forum 25, 191-202. https://doi.org/10.1111/j.1477-8947.2001.tb00761.x

Vivoda, V., Kemp, D., Owen, J., 2019. Regulating the social aspects of mine closure in three Australian states. J. Energy Nat. Resour. Law 1-20. https://doi.org/10.1080/02646811.2019.1608030

White, G., 2006. Cultures in collision: Traditional Knowledge and Euro-Canadian governance processes in Northern land-claim boards. Arctic 59, 401-414. http://doi.org/10.14430/arctic289

Wilson, L., 2004. Riding the resource roller coaster: understanding socioeconomic differences between mining communities. Rural Sociol. 69, 261-281. https://doi.org/10.1526/003601104323087606

Worrall, R., Neil, D., Brereton, D., Mulligan, D., 2009. Towards a sustainability criteria and 
indicators framework for legacy mine land. J. Clean. Prod. 17, 1426-1434.

https://doi.org/10.1016/j.jclepro.2009.04.013

Xavier, A.M., Veiga, M.M., Zyl, D. Van, 2015. Introduction and assessment of a socio-economic mine closure framework. J. Manag. Sustain. 5, 38-49. https://doi.org/10.5539/jms.v5n1p38

Zou, L., Thomalla, F., 2010. Social vulnerability to coastal hazards in South-east Asia: a synthesis of research insights, in: Hoanh, C.T., Szuster, B.W., Suan-Pheng, K., Ismail, A.M., Noble, A.D. (Eds.), Tropical Deltas and Coastal Zones: Food Production, Communities and Environment at the Land-Water Interface. CABI, Oxfordshire; Cambridge, pp. 367-383. https://doi.org/10.1079/9781845936181.0133 